\title{
Analisis Diskriptif Technologi Acceptance Model Pada Penerapan Blended Learning
}

\author{
Elistya Rimawati ${ }^{1)}$, Wawan Laksito Yuly Saptomo ${ }^{2)}$ \\ 1) Program Studi Sistem Informasi, STMIK Sinar Nusantara \\ 2) Program Studi Teknik Informatika, STMIK Sinar Nusantara ${ }^{1)}$ \\ ${ }^{1)}$ elistyarimawati@gmail.com, ${ }^{2}$ wlaksito@ sinus.ac.id
}

\begin{abstract}
The Blended Learning learning model is a system that collaborates classroom face-to-face learning with online learning. This study aims to measure the acceptance of the Blended Learning learning model among students. The variables developed refer to the Technology Acceptance Model (TAM), which is a model of user acceptance of information systems. The data obtained were analyzed by descriptive statistics and qualitative analysis. The results showed that in general the use of the Blended Learning learning model could be accepted by students in the category of Good approaching is Very Good. The mean value of all aspects reached a value of 3.94 on a scale of 5 (79\%). The results of qualitative analysis were in line with the results of quantitative analysis. Students received good use of e-Learning while maintaining face-to-face learning activities in class. The results of this study can be used as a basis for recommending the selection of learning methods in universities Keywords : Blended Learning, Acceptance, TAM, Descriptive Analysis
\end{abstract}

\section{PENDAHULUAN}

Perubahan dunia kini tengah memasuki era revolusi industri 4.0 atau revolusi industri dunia keempat dimana teknologi informasi telah menjadi basis dalam kehidupan manusia. Segala hal menjadi tanpa batas (borderless) dengan penggunaan daya komputasi dan data yang tidak terbatas (unlimited), karena dipengaruhi oleh perkembangan internet dan teknologi digital yang masih sebagai tulang punggung pergerakan dan konektivitas manusia dan mesin. Era ini juga akan mendisrupsi berbagai aktivitas manusia, termasuk di dalamnya bidang ilmu pengetahuan dan teknologi (iptek) serta pendidikan tinggi. Sistem pembelajaran di perguruan tinggi perlu penyesuaian dengan mengintegrasikan objek fisik, digital dan manusia untuk menghasilkan lulusan perguruan tinggi yang kompetitif dan terampil terutama dalam aspek data literacy, technological literacy, and human literacy. Faktor teknologi, manusia, dan organisasi memiliki hubungan yang kuat, serta searah (positif) dan signifikan terhadap net benefit. Semakin baik dan tepat hubungan ketiga faktor tersebut, maka semakin tinggi manfaat yang didapatkan dari penerapan E-Learning.(Poluan, Lumenta, \& Sinsuw, 2014).

Proses pembelajaran adalah proses komunikasi yang melibatkan instruktur sebagai pengirim pesan dan mahasiswa sebagai penerima pesan. Di dalam proses pengiriman pesan menggunakan media komunikasi. Model pembelajaran Blended Learning adalah sistem yang mengkolaborasikan pembelajaran tatap muka kelas dengan pembelajaran online memanfaatkan E-Learning. Pembelajaran dilaksanakan dengan tatap muka secara offline (ceramah, diskusi, pembimbingan tugas) dan interaksi online menggunakan aplikasi $E$ Learning (penyebaran informasi, distribusi materi, diskusi, penugasan, kuis).

Technology Acceptance Model (TAM) merupakan metoda pengukuran tingkat penerimaan teknologi. TAM mengukur presepsi kemudahan dan kemanfaatan yang berpengaruh terhadap tingkat penerimaan teknologi. Penerimaan Blended Learning dari sudut pandang instruktur menunjukkan bahwa sebagian besar konstruk yang ditanyakan kepada responden mendapatkan jawaban yang positif setuju (Mutawa, 2017). Instruktur 
yang memiliki dedikasi dan tanggung jawab yang tinggi terhadap peningkatan mutu pembelajaran, akan melihat model ini sebagai suatu cara dalam mengembangkan kemampuan dirinya, melakukan inovasi dan pengembangan dalam pembelajaran (Wijaya, 2012).

Kesuksesan penggunaan media komunikasi pembelajaran perlu diukur dari semua komponen komunikasi. Penerimaan teknologi pembelajaran perlu diukur dari sisi instruktur dan dari sisi mahasiswa. Pengukuran penerimaan model pembelajaran Blended Learning di kalangan mahasiswa diperlukan karena mahasiswa sebagai subyek pembelajaran. Dalam pendekatan pembelajaran berpusat pada mahasiswa keterlibatan mahasiswa secara aktif menjadi basis proses pembelajaran.

\section{TINJAUAN PUSTAKA}

\subsection{Blended Learning}

Blended Learning secara sederhana dapat didefinisikan sebagai perpaduan metode belajar tatap muka (di dalam kelas) dengan materi yang diberikan secara online. Blended Learning menggabungkan ciri-ciri terbaik dari pembelajaran di kelas (tatap muka) dan ciriciri terbaik pembelajaran online (Husamah, 2014). Metode ini sangat efisien karena selain mahasiswa bisa mendapatkan perkuliahan tatap muka dengan dosen di dalam kelas, mereka juga bisa mengakses materi yang diberikan secara online di manapun mereka berada. Karakter generasi $\mathrm{Z}$ yang menyukai hal instan memang sangat cocok jika menggunakan pembelajaran ini karena sifatnya yang fleksibel, efektif, dan efisien. Tetapi perlu digaris bawahi bahwa pengetahuan penggunaan teknologi informasi mereka sangat berbeda-beda. Kebanyakan dari mereka hanya sebatas pada pengguna gadget, bukan pengguna teknologi (Purnomo, Ratnawati, \& Aristin, 2016). Dari segi pendidikan, Blended Learning akan memberikan dua keuntungan, baik untuk pengajar maupun mahasiswa melalui istilah yang disebut dengan "differentiated instruction" (keberagaman instruksi) dan "pacing and attendance" (kenyamanan dan kehadiran). Differentiated instruction melibatkan pembelajaran yang didesain untuk mahasiswa. Dalam hal ini, pengajar akan menentukan muatan kurikulum, lingkungan dan aktivitas pembelajaran yang bisa diberikan secara online dan tatap muka berdasarkan tingkat kesukaran, minat dan gaya belajar mahasiswa. "Pacing and attendance", mahasiswa secara mandiri bisa menentukan kapan saatnya belajar sesuai dengan kondisi individual (Saptomo, 2018).

\subsection{Technology Acceptance Model (TAM)}

Kontruk TAM terdiri dari perceived usefulness, perceived ease of use, attitude toward using, behavioral intention, dan actual usage. Secara garis besar, model dapat dibedakan menjadi dua bagian, kepercayaan dan penerimaan. Kepercayaan meliputi perceived usefulness dan perceived ease of use, sedangkan penerimaan meliputi attitude toward using, behavioral intention, dan actual usage (Davis, 1989). Bentuk hubungan antar konstruk ditunjukan pada Gambar 1.

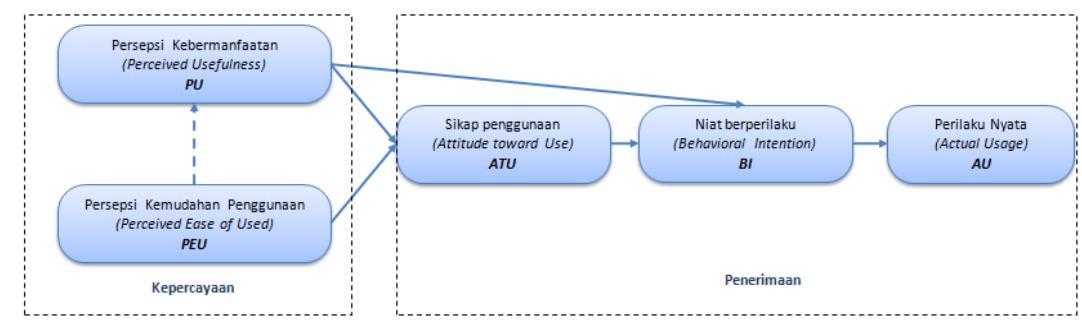

Gambar 1. Teknologi Aceptance Model 
Perceived ease of use dapat didefinisikan sebagai keyakinan pengguna bahwa menggunakan sebuah sistem tidak memerlukan usaha yang keras. Hal ini mencakup kemudahan dalam menggunakan sistem sesuai dengan keinginan pengguna. Persepsi kemudahan dapat memberikan alasan pada pengguna untuk menggunakan sebuah sistem yang baru. Selain itu, persepsi kemudahan juga menjelaskan bahwa sistem yang baru dapat diterima oleh pengguna (Fatmawati, 2015). Persepsi kemudahan akan berpengaruh pada persepsi kegunaan dan sikap perilaku menggunakan sistem. Perceived usefulness merupakan keyakinan bahwa penggunaan sistem akan meningkatkan kinerja pengguna. Sehingga, apabila pengguna merasa yakin dan percaya bahwa sistem tersebut bisa berguna, maka pengguna akan menggunakannya. Sebaliknya, apabila pengguna merasa tidak yakin dan tidak percaya bahwa sistem tersebut bisa berguna, maka pengguna tidak akan menggunakannya (Fatmawati, 2015).

Attitude toward using sebagai sebuah sikap terhadap penggunaan sistem yang dapat berbentuk penerimaan maupun penolakan. Respon tersebut merupakan dampak bila seseorang menggunakan teknologi untuk menyelesaikan pekerjaannya. Sikap ini kemudian berpengaruh pada seseorang untuk menyukai atau tidak menyukai sesuatu. Selain itu, sikap juga berpengaruh dalam hal menggunakan atau tidak menggunakan suatu sistem. Sikap merupakan salah satu faktor yang mempengaruhi perilaku individual (Davis, 1989).

Behavioral intention to use merupakan suatu kecenderungan perilaku untuk tetap menggunakan suatu teknologi. Tingkat penggunaan teknologi seseorang bisa diprediksi dari sikap perhatiannya terhadap teknologi tersebut (Librado, 2017). Minat perilaku penggunaan berpengaruh terhadap penggunaan nyata. Actual usage behavior merupakan kondisi nyata dalam penggunaan sistem. Hal ini dikonsepkan dalam bentuk pengukuran terhadap frekuensi serta durasi waktu untuk penggunaan teknologi. Apabila seseorang meyakini bahwa sebuah sistem mudah digunakan serta akan meningkatkan produktifitas, maka ia akan merasa puas. Kemudahan dan peningkatan produktifitas ini terlihat dari penggunaan nyata teknologi (Alharbi \& Drew, 2014). Penggunaan nyata menunjukkan hasil akhir dari penerimaan teknologi. Apabila pengguna merasakan kemudahan dan kegunaan teknologi, maka mereka akan memperlihatkan sikap yang cenderung menerima teknologi tersebut. Kemudian, sikap menerima tersebut akan mempengaruhi minat penggunaan teknologi selanjutnya dan pengguna akan menggunakan teknologi tersebut secara berulang-ulang serta tidak menunjukkan keberatan atau kesulitan yang berarti.

\section{METODE PENELITIAN}

Penelitian ini menggunakan variabel-variabel dalam metode Technology Acceptance Model (TAM). Setiap Variabel di lihat dari beberapa dimensi, dan setiap dimensi diukur berdasarkan indikator-indikator. Daftar konstruk, dimensi dan indikator diperlihatkan pada Tabel 1.

Tabel 1. Variabel, Dimensi, Indikator

\begin{tabular}{|l|l|l|}
\hline \multicolumn{1}{|c|}{$\begin{array}{c}\text { Variabel/ } \\
\text { Konstruk }\end{array}$} & \multicolumn{1}{|c|}{ Dimensi } & \multicolumn{1}{c|}{ Indikator } \\
\hline $\begin{array}{l}\text { Persepsi } \\
\text { Kemudahan }\end{array}$ & Kemudahan dipelajari & Kemudahan Dipelajari \\
\cline { 2 - 3 } $\begin{array}{l}\text { Penggunaan } \\
\text { (Perceived ease of } \\
\text { used-PEU) }\end{array}$ & Fyarat keahlian khusus pengguna \\
\cline { 2 - 3 } & Interaksi & Interaksi dengan fitur dan sistem menu \\
\cline { 2 - 3 } & & Fleksibilitas tempat dan waktu mengakses \\
\cline { 2 - 3 } & & Flesibilitas spesifikasi komputer (alat akses) \\
\hline
\end{tabular}


Tabel 2. Lanjutan Variabel, Dimensi, Indikator

\begin{tabular}{|c|c|c|}
\hline $\begin{array}{l}\text { Variabel/ } \\
\text { Konstruk }\end{array}$ & Dimensi & Indikator \\
\hline & Mudah digunakan & Kemudahan cara penggunaan \\
\hline \multirow{5}{*}{$\begin{array}{l}\text { Persepsi } \\
\text { Kemanfaatan } \\
\text { (Perceived } \\
\text { Usefulness-PU) }\end{array}$} & \multirow[t]{2}{*}{ Efisiensi } & Kecepatan penerimaan informasi \\
\hline & & $\begin{array}{l}\text { Kemudahan interaksi dengan peserta } \\
\text { pembelajaran (Dosen-mahasiswa, mahasiswa- } \\
\text { mahasiswa) }\end{array}$ \\
\hline & \multirow[t]{2}{*}{ Meningkatkan kinerja } & Kuantitas materi pembelajaran yang diperoleh \\
\hline & & Kemudahan pengerjaan dan pengumpulan tugas \\
\hline & Efektifitas & Pencapaian tujuan belajar (hasil belajar) \\
\hline \multirow{4}{*}{$\begin{array}{l}\text { Sikap penggunaan } \\
\text { (Attitude toward } \\
\text { use-ATU) }\end{array}$} & Kesenangan & $\begin{array}{l}\text { Kesenangan dengan sistem pembelajaran } \\
\text { Blended Learning }\end{array}$ \\
\hline & Kenyamanan & $\begin{array}{l}\text { Kenyamanan dalam belajar dengan sistem } \\
\text { pembelajaran Blended Learning }\end{array}$ \\
\hline & Kepuasan & $\begin{array}{l}\text { Kepuasan dengan sistem pembelajaran Blended } \\
\text { Learning }\end{array}$ \\
\hline & Penerimaan & $\begin{array}{l}\text { Penerimaan penggunaan sistem Blended } \\
\text { Learning }\end{array}$ \\
\hline \multirow{5}{*}{$\begin{array}{l}\text { Niat berperilaku } \\
\text { (Behavioral } \\
\text { Intention-BI) }\end{array}$} & \multirow[t]{2}{*}{ Motivasi Penggunaan } & Motivasi penggunaan pembelajaran online \\
\hline & & Motivasi penggunaan pembelajaran offline \\
\hline & $\begin{array}{l}\text { Motivasi Pengembangan } \\
\text { Diri }\end{array}$ & Motivasi untuk menyediakan sarana yang baik \\
\hline & \multirow{2}{*}{$\begin{array}{l}\text { Motivasi ke Pengguna } \\
\text { Lain }\end{array}$} & Rekomendasi kepada matakuliah/dosen lain \\
\hline & & Rekomendasi kepada mahasiswa lain \\
\hline \multirow{7}{*}{$\begin{array}{l}\text { Perilaku Nyata } \\
\text { (Actual Usage-AU) }\end{array}$} & \multirow[t]{2}{*}{ Frekuensi Penggunaan } & $\begin{array}{l}\text { Frekuensi penggunaan E-Learning (kuliah } \\
\text { online) }\end{array}$ \\
\hline & & Frekuensi kehadiran kuliah offline \\
\hline & \multirow{2}{*}{ Durasi Penggunaan } & Durasi Penggunaan saat jam kuliah \\
\hline & & Durasi Penggunaan diluar jam kuliah \\
\hline & \multirow{3}{*}{ Peruntukan Penggunaan } & $\begin{array}{l}\text { Mengakses E-Learning untuk mendapatkan } \\
\text { informasi perkuliahan }\end{array}$ \\
\hline & & $\begin{array}{l}\text { Mengakses E-Learning untuk kepentingan } \\
\text { tugas-tugas perkuliahan }\end{array}$ \\
\hline & & $\begin{array}{l}\text { Interaksi dalam diskusi online (bertanya, } \\
\text { menyampaikan pendapat/komentar) }\end{array}$ \\
\hline
\end{tabular}

Populasi dalam penelitian ini adalah Mahasiswa STMIK Sinar Nusantara Surakarta, yang telah menerima model pembelajaran Blended Learning minimal 1 (satu) semester. Sistem pembelajaran online menggunakan Google Classroom. Teknik pengambilan sampel yang digunakan dalam penelitian ini adalah proportionate stratified random sampling, yang merupakan teknik untuk populasi penelitian yang tidak homogen serta berstrata secara proporsional (Sugiyono 2015:82). Penyebaran kuesioner dengan menggunakan kuesioner online yang ditautkan di E-Learning. Ada dua jenis pertanyaan yang dibuat dalam kuesioner yaitu pertanyaan tertutup dan pertanyaan terbuka. Pertanyaan tertutup digunakan untuk mengukur persepsi mahasiswa terhadap setiap variabel dalam TAM. Pertanyaan-pertanyaan ini merepresentasikan setiap indikator-indikator variabel. Pengukuran jawaban menggunakan skala Linkert dari nilai 0 sd 5. Hasilnya dilakukan analisis kuantitatif dengan statistik diskriptif. Pertanyaan terbuka digunakan untuk mendapatkan persepsi umum mahasiswa terhadap penggunaan Blended Learning. Jawaban mahasiswa dianalisis secara kualitatif.

Analisis diskriptif dilakukan terhadap seluruh data tanpa pengelompokan. Data yang diperoleh dari kuesioner dilakukan analisa frekuensi jawaban dan mean untuk masing- 
masing indikator. Dari data frekuensi dan mean jawaban masing-masing indikator selanjutnya dilakukan analisis data terhadap nilai Indikator, Dimensi, dan Variabel. Nilai yang dihitung adalah nilai mean dan prosentase nilai yang diperoleh dari nilai maksimal 5 dari setiap indikator. Berdasarkan nilai indikator yang diperoleh dihitung rerata (mean) nilai indikator dalam satu Dimensi yang sama, nilai ini menjadi nilai Dimensi. Selanjutnya berdasarkan nilai Dimensi di hitung rerata nilai Dimensi dalam satu Variabel yang sama, nilai ini menjadi nilai Variabel. Berdasarkan nilai yang diperoleh selanjutnya dianalisis dengan pengkategorian nilai sebagai berikut : $\quad 0 \leq$ prosen nilai $<40$ kategori tidak baik; 40 $\leq$ prosen nilai $<60$ kategori cukup baik; $60 \leq$ prosen nilai $<80$ kategori baik; $80 \leq$ prosen nilai $<100$ kategori sangat baik. Alur penelitian digambarkan pada Gambar 1.

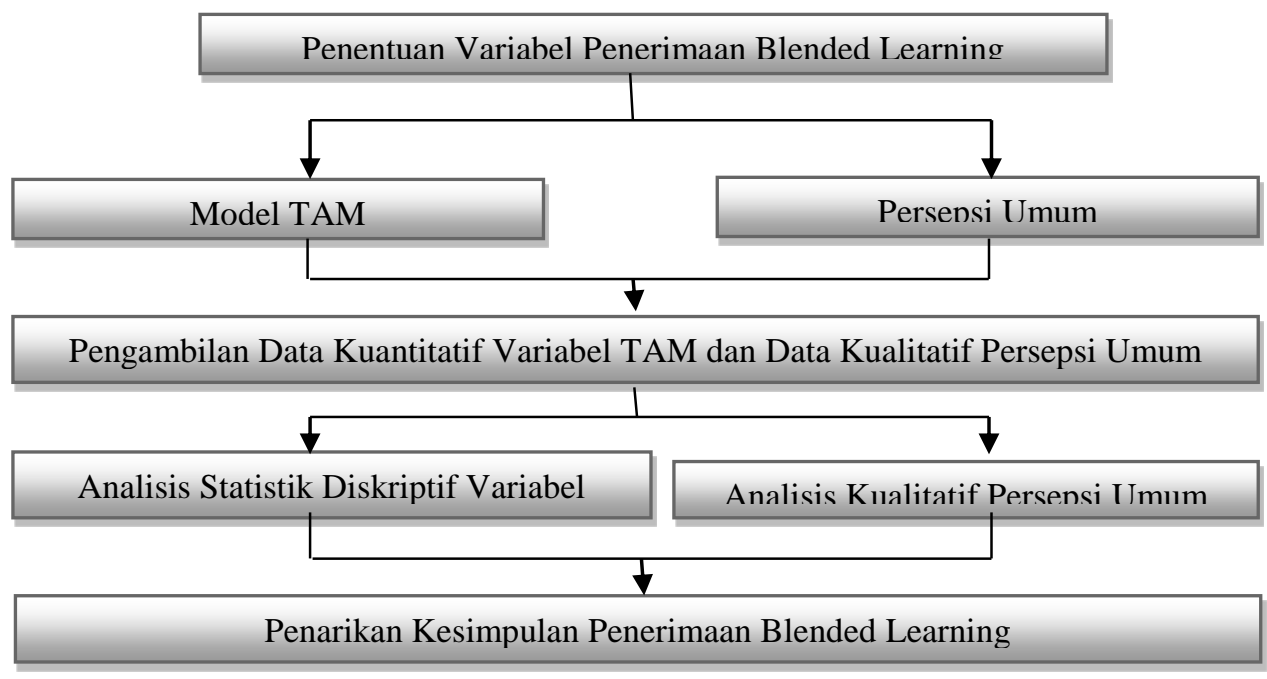

Gambar 1. Alur Penelitian

\section{HASIL DAN PEMBAHASAN}

\subsection{Data dan Statistik Diskriptif}

Peneliti menyebarkan kuesioner dengan mengirimkan kuesioner online kepada 300 mahasiswa dan kuesioner yang kembali sebanyak 288. Distribusi sampel data penelitian berdasarkan program studi dan kelompok kelas ditunjukkan pada Tabel 2. Frekuensi jawaban seluruh responden ditunjukkan pada Tabel 3. Dari nilai mean indikator dihitung nilai mean Dimensi variabel berdasarkan nilai-nilai mean Indikator dalam kelompok dimensi yang sama. Dari kelompok dimensi dihitung nilai mean dari Variabel-variabel. Hasil perhitungan mean dari Indikator, Dimensi, dan Variabel ditunjukkan pada Tabel 4. Tabel statistik variabel ditunjukkan pada Tabel 5.

Tabel 2. Data Kuesioner berdasarkan strata

\begin{tabular}{|c|c|c|c|}
\hline \multirow{2}{*}{ Kelas } & Prodi & \multicolumn{2}{|c|}{ Kuesioner yang kembali } \\
\hline \multirow{2}{*}{ Siang } & TI-S1 & 155 & \multirow{2}{*}{200} \\
\cline { 2 - 3 } & SI-S1 & 45 & \multirow{2}{*}{88} \\
\hline \multirow{2}{*}{ Malam } & TI-S1 & 67 & 288 \\
\cline { 2 - 3 } & SI-S1 & \multicolumn{2}{|c|}{21} \\
\hline \multicolumn{2}{|c|}{ Total } & \multicolumn{2}{c}{288} \\
\hline
\end{tabular}


Tabel 3. Frekuensi jawaban dan Mean seluruh responden

\begin{tabular}{|c|c|c|c|c|c|c|c|c|c|c|c|c|c|}
\hline \multirow{3}{*}{ Kode } & \multicolumn{10}{|c|}{ Frekuensi Jawaban dan \% Frekuensi } & \multirow{2}{*}{\multicolumn{2}{|c|}{$\begin{array}{c}\text { Total } \\
\text { Respondent } \\
\end{array}$}} & \multirow{3}{*}{ Mean } \\
\hline & \multicolumn{2}{|c|}{1} & \multicolumn{2}{|c|}{2} & \multicolumn{2}{|c|}{3} & \multicolumn{2}{|c|}{4} & \multicolumn{2}{|c|}{5} & & & \\
\hline & fr & $\%$ & fr & $\%$ & fr & $\%$ & fr & $\%$ & fr & $\%$ & & 38 & \\
\hline PEU 1 & 3 & $1 \%$ & 4 & $1 \%$ & 58 & $20 \%$ & 132 & $46 \%$ & 91 & $32 \%$ & 288 & $100 \%$ & 4.06 \\
\hline PEU 2 & 1 & $0 \%$ & 16 & $6 \%$ & 62 & $22 \%$ & 116 & $40 \%$ & 93 & $32 \%$ & 288 & $100 \%$ & 3.99 \\
\hline PEU 3 & 1 & $0 \%$ & 6 & $2 \%$ & 46 & $16 \%$ & 137 & $48 \%$ & 98 & $34 \%$ & 288 & $100 \%$ & 4.13 \\
\hline PEU 4 & 3 & $1 \%$ & 8 & $3 \%$ & 31 & $11 \%$ & 64 & $22 \%$ & 182 & $63 \%$ & 288 & $100 \%$ & 4.44 \\
\hline PEU 5 & 1 & $0 \%$ & 3 & $1 \%$ & 30 & $10 \%$ & 87 & $30 \%$ & 167 & $58 \%$ & 288 & $100 \%$ & 4.44 \\
\hline PEU 6 & 1 & $0 \%$ & 4 & $1 \%$ & 40 & $14 \%$ & 107 & $37 \%$ & 136 & $47 \%$ & 288 & $100 \%$ & 4.30 \\
\hline PU 1 & 2 & $1 \%$ & 9 & $3 \%$ & 67 & $23 \%$ & 119 & $41 \%$ & 91 & $32 \%$ & 288 & $100 \%$ & 4.00 \\
\hline PU 2 & 2 & $1 \%$ & 14 & $5 \%$ & 89 & $31 \%$ & 114 & $40 \%$ & 69 & $24 \%$ & 288 & $100 \%$ & 3.81 \\
\hline PU 3 & 4 & $1 \%$ & 7 & $2 \%$ & 113 & $39 \%$ & 111 & $39 \%$ & 53 & $18 \%$ & 288 & $100 \%$ & 3.70 \\
\hline PU 4 & 3 & $1 \%$ & 5 & $2 \%$ & 30 & $10 \%$ & 94 & $33 \%$ & 156 & $54 \%$ & 288 & $100 \%$ & 4.37 \\
\hline PU 5 & 2 & $1 \%$ & 6 & $2 \%$ & 94 & $33 \%$ & 147 & $51 \%$ & 39 & $14 \%$ & 288 & $100 \%$ & 3.75 \\
\hline ATU 1 & 2 & $1 \%$ & 5 & $2 \%$ & 79 & $27 \%$ & 149 & $52 \%$ & 53 & $18 \%$ & 288 & $100 \%$ & 3.85 \\
\hline ATU 2 & 3 & $1 \%$ & 7 & $2 \%$ & 97 & $34 \%$ & 140 & $49 \%$ & 41 & $14 \%$ & 288 & $100 \%$ & 3.73 \\
\hline ATU 3 & 2 & $1 \%$ & 9 & $3 \%$ & 108 & $38 \%$ & 127 & $44 \%$ & 42 & $15 \%$ & 288 & $100 \%$ & 3.69 \\
\hline ATU 4 & 2 & $1 \%$ & 4 & $1 \%$ & 67 & $23 \%$ & 141 & $49 \%$ & 74 & $26 \%$ & 288 & $100 \%$ & 3.98 \\
\hline BI 1 & 2 & $1 \%$ & 7 & $2 \%$ & 77 & $27 \%$ & 136 & $47 \%$ & 66 & $23 \%$ & 288 & $100 \%$ & 3.89 \\
\hline BI 2 & 8 & $3 \%$ & 8 & $3 \%$ & 59 & $20 \%$ & 100 & $35 \%$ & 113 & $39 \%$ & 288 & $100 \%$ & 4.05 \\
\hline BI 3 & 1 & $0 \%$ & 7 & $2 \%$ & 72 & $25 \%$ & 150 & $52 \%$ & 58 & $20 \%$ & 288 & $100 \%$ & 3.89 \\
\hline BI 4 & 1 & $0 \%$ & 12 & $4 \%$ & 69 & $24 \%$ & 111 & $39 \%$ & 95 & $33 \%$ & 288 & $100 \%$ & 4.00 \\
\hline BI 5 & 1 & $0 \%$ & 4 & $1 \%$ & 49 & $17 \%$ & 120 & $42 \%$ & 114 & $40 \%$ & 288 & $100 \%$ & 4.19 \\
\hline AU 1 & 2 & $1 \%$ & 19 & $7 \%$ & 128 & $44 \%$ & 116 & $40 \%$ & 23 & $8 \%$ & 288 & $100 \%$ & 3.48 \\
\hline AU 2 & 0 & $0 \%$ & 6 & $2 \%$ & 32 & $11 \%$ & 112 & $39 \%$ & 138 & $48 \%$ & 288 & $100 \%$ & 4.33 \\
\hline AU 3 & 3 & $1 \%$ & 37 & $13 \%$ & 147 & $51 \%$ & 82 & $28 \%$ & 19 & $7 \%$ & 288 & $100 \%$ & 3.27 \\
\hline AU 4 & 2 & $1 \%$ & 26 & $9 \%$ & 151 & $52 \%$ & 94 & $33 \%$ & 15 & $5 \%$ & 288 & $100 \%$ & 3.33 \\
\hline AU 5 & 0 & $0 \%$ & 5 & $2 \%$ & 30 & $10 \%$ & 138 & $48 \%$ & 115 & $40 \%$ & 288 & $100 \%$ & 4.26 \\
\hline AU 6 & 0 & $0 \%$ & 2 & $1 \%$ & 26 & $9 \%$ & 124 & $43 \%$ & 136 & $47 \%$ & 288 & $100 \%$ & 4.37 \\
\hline AU 7 & 4 & $1 \%$ & 23 & $8 \%$ & 117 & $41 \%$ & 94 & $33 \%$ & 50 & $17 \%$ & 288 & $100 \%$ & 3.57 \\
\hline
\end{tabular}

Tabel 4. Nilai Indikator, Dimensi, dan Variabel

\begin{tabular}{|c|c|c|c|c|c|c|c|c|}
\hline \multirow[b]{2}{*}{ Variabel } & \multirow[b]{2}{*}{ Dimensi } & \multirow[b]{2}{*}{ Kode } & \multicolumn{2}{|c|}{ Indikator } & \multicolumn{2}{|c|}{ Dimensi } & \multicolumn{2}{|c|}{ Variabel } \\
\hline & & & Mean & $\begin{array}{c}\% \\
\text { Capaian }\end{array}$ & Mean & $\begin{array}{c}\% \\
\text { Capaian }\end{array}$ & Mean & $\begin{array}{c}\% \\
\text { Capaian }\end{array}$ \\
\hline \multirow{5}{*}{$\begin{array}{l}\text { Persepsi } \\
\text { Kemudahan } \\
\text { Penggunaan } \\
\text { (Perceived } \\
\text { ease of used- } \\
\text { PEU) }\end{array}$} & $\begin{array}{l}\text { Kemudahan } \\
\text { dipelajari }\end{array}$ & $\begin{array}{l}\text { PEU } 1 \\
\text { PEU } 2\end{array}$ & $\begin{array}{l}4,1 \\
4.0\end{array}$ & $\begin{array}{l}81 \% \\
80 \%\end{array}$ & 4,0 & $80 \%$ & \multirow{5}{*}{4,2} & \multirow{5}{*}{$84 \%$} \\
\hline & $\begin{array}{l}\text { Kemudahan } \\
\text { berinteraksi }\end{array}$ & PEU 3 & 4,1 & $83 \%$ & 4,1 & $83 \%$ & & \\
\hline & \multirow{2}{*}{ Fleksibilitas } & PEU 4 & 4,4 & $89 \%$ & 4.4 & $89 \%$ & & \\
\hline & & PEU 5 & 4,4 & $89 \%$ & 4,4 & $89 \%$ & & \\
\hline & $\begin{array}{l}\text { Mudah } \\
\text { digunakan }\end{array}$ & PEU 6 & 4,3 & $86 \%$ & 4,3 & $86 \%$ & & \\
\hline
\end{tabular}


Tabel 4. Lanjutan Nilai Indikator, Dimensi, dan Variabel

\begin{tabular}{|c|c|c|c|c|c|c|c|c|}
\hline \multirow[b]{2}{*}{ Variabel } & \multirow[b]{2}{*}{ Dimensi } & \multirow[b]{2}{*}{ Kode } & \multicolumn{2}{|c|}{ Indikator } & \multicolumn{2}{|c|}{ Dimensi } & \multicolumn{2}{|c|}{ Variabel } \\
\hline & & & Mean & $\begin{array}{c}\% \\
\text { Capaian }\end{array}$ & Mean & $\begin{array}{c}\% \\
\text { Capaian }\end{array}$ & Mean & $\begin{array}{c}\% \\
\text { Capaian }\end{array}$ \\
\hline \multirow{5}{*}{$\begin{array}{c}\text { Persepsi } \\
\text { Kemanfaatan } \\
\text { (Perceived } \\
\text { Usefulness- } \\
\text { PU) }\end{array}$} & \multirow{2}{*}{ Efisiensi } & PU 1 & 4,0 & $80 \%$ & & & \multirow{5}{*}{ 3,9 } & \multirow{5}{*}{ 79\% } \\
\hline & & PU 2 & 3,8 & $76 \%$ & 5,9 & 1070 & & \\
\hline & \multirow{2}{*}{$\begin{array}{l}\text { Meningkatka } \\
\text { n kinerja }\end{array}$} & PU 3 & 3,7 & $74 \%$ & \multirow{2}{*}{4,0} & \multirow{2}{*}{$81 \%$} & & \\
\hline & & PU 4 & 4,4 & $87 \%$ & & & & \\
\hline & Efektifitas & PU 5 & 3,7 & $75 \%$ & 3,7 & $75 \%$ & & \\
\hline \multirow{4}{*}{$\begin{array}{c}\text { Sikap } \\
\text { penggunaan } \\
\text { (Attitude } \\
\text { toward use - } \\
\text { ATU) }\end{array}$} & Kesenangan & ATU 1 & 3,9 & $77 \%$ & 3,9 & $77 \%$ & \multirow{4}{*}{3,8} & \multirow{4}{*}{$76 \%$} \\
\hline & Kenyamanan & ATU 2 & 3,7 & $75 \%$ & 3,7 & $75 \%$ & & \\
\hline & Kepuasan & ATU 3 & 3,7 & $74 \%$ & 3,7 & $74 \%$ & & \\
\hline & Penerimaan & ATU 4 & 4,0 & $80 \%$ & 4,0 & $80 \%$ & & \\
\hline \multirow{5}{*}{$\begin{array}{c}\quad \text { Niat } \\
\text { berperilaku } \\
\text { (Behavioral } \\
\text { Intention-BI) }\end{array}$} & \multirow{2}{*}{$\begin{array}{l}\text { Motivasi } \\
\text { Penggunaan }\end{array}$} & BI 1 & 3,9 & $78 \%$ & \multirow{2}{*}{4,0} & \multirow{2}{*}{$79 \%$} & \multirow{5}{*}{4,0} & \multirow{5}{*}{$80 \%$} \\
\hline & & BI 2 & 4,0 & $81 \%$ & & & & \\
\hline & $\begin{array}{l}\text { Motivasi } \\
\text { pengembanga } \\
\text { n diri }\end{array}$ & BI 3 & 3,9 & $78 \%$ & 3,9 & $78 \%$ & & \\
\hline & \multirow{2}{*}{\begin{tabular}{|l|}
$\begin{array}{l}\text { Motivasi ke } \\
\text { pengguna lain }\end{array}$ \\
\end{tabular}} & BI 4 & 4,0 & $80 \%$ & \multirow{2}{*}{4,1} & \multirow{2}{*}{$82 \%$} & & \\
\hline & & BI 5 & 4,2 & $84 \%$ & & & & \\
\hline \multirow{7}{*}{$\begin{array}{c}\text { Perilaku Nyata } \\
\text { (Actual } \\
\text { Usage-AU) }\end{array}$} & \multirow{2}{*}{$\begin{array}{l}\text { Frekuensi } \\
\text { penggunaan }\end{array}$} & AU 1 & 3,5 & $70 \%$ & \multirow{2}{*}{$3, .9$} & \multirow{2}{*}{$78 \%$} & \multirow{7}{*}{3,8} & \multirow{7}{*}{$76 \%$} \\
\hline & & AU 2 & 4,3 & $87 \%$ & & & & \\
\hline & Durasi & AU 3 & 3,3 & $65 \%$ & & $66 \%$ & & \\
\hline & penggunaan & AU 4 & 3,3 & $67 \%$ & 3,3 & & & \\
\hline & \multirow{3}{*}{$\begin{array}{l}\text { Peruntukan } \\
\text { penggunaan }\end{array}$} & AU 5 & 4,3 & $85 \%$ & \multirow{3}{*}{4,1} & & & \\
\hline & & AU 6 & 4,4 & $87 \%$ & & $81 \%$ & & \\
\hline & & AU 7 & 3,6 & $71 \%$ & & & & \\
\hline
\end{tabular}

Tabel 5. Statistik Diskriptif Variabel

\begin{tabular}{|l|r|r|r|r|r|}
\hline \multicolumn{1}{|c|}{ Statistik } & \multicolumn{1}{c|}{$P E U$} & \multicolumn{1}{c|}{$P U$} & \multicolumn{1}{c|}{$A T U$} & \multicolumn{1}{c|}{$B I$} & $A U$ \\
\hline Mean & $\mathbf{4 , 2 2}$ & $\mathbf{3 , 9 1}$ & $\mathbf{3 , 8 1}$ & $\mathbf{4 , 0 0}$ & $\mathbf{3 , 8 0}$ \\
\hline Standard Error & 0,03 & 0,04 & 0,04 & 0,04 & 0,03 \\
\hline Median & 4,33 & 4,00 & 4,00 & 4,00 & 3,71 \\
\hline Mode & 4,33 & 4,00 & 4,00 & 4,00 & 3,71 \\
\hline Standard Deviation & 0,59 & 0,62 & 0,66 & 0,60 & 0,49 \\
\hline Sample Variance & 0,35 & 0,39 & 0,44 & 0,36 & 0,24 \\
\hline Kurtosis & 3,36 & 0,99 & 0,53 & 1,55 & 0,53 \\
\hline Skewness & $-1,30$ & $-0,50$ & $-0,30$ & $-0,66$ & 0,00 \\
\hline Range & 4,00 & 4,00 & 4,00 & 4,00 & 3,14 \\
\hline Minimum & 1,00 & 1,00 & 1,00 & 1,00 & 1,86 \\
\hline Maximum & 5,00 & 5,00 & 5,00 & 5,00 & 5,00 \\
\hline Sum & 1216.67 & 1125,50 & 1097,50 & 1153,00 & 1094,29 \\
\hline Count & $\mathbf{2 8 8 , 0 0}$ & $\mathbf{2 8 8 , 0 0}$ & $\mathbf{2 8 8 , 0 0}$ & $\mathbf{2 8 8 . 0 0}$ & $\mathbf{2 8 8 , 0 0}$ \\
\hline Confidence Level(95.0\%) & 0.07 & 0.07 & 0.08 & 0.07 & 0.06 \\
\hline
\end{tabular}

Tabel Statistik Diskriptif Variabel pada Tabel 5. menunjukkan bahwa data mempunyai tingkat variansi antara 0,24 sampai dengan 0,44 dan selang kepercayaan pada kategori baik diatas 95\%, hal ini ditunjukkan dengan nilai Standard Error untuk semua variabel di bawah $5 \%$, yang berarti data dapat mewakili polulasi dengan baik. Nilai Kurtosis untuk semua variabel diatas 0,263 ( PEU : 3,36; PU : 0,99; ATU : 0,53; BI : 1,55; AU : 0,53) yang berarti untuk semua variabel data terdistribusi Normal.

Nilai-nilai mean variabel dari setiap variabel diperlihatkan dalam bentuk diagram pencar pada Gambar 2. 


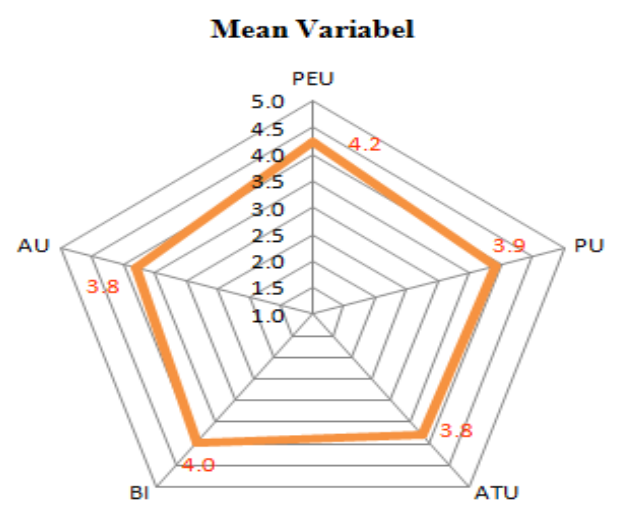

Gambar 2. Diagram Pencar Nilai Mean Variabel TAM

Dari diagram pencar pada Gambar 2. terlihat bahwa masing masing variabel memiliki nilai yang seimbang antara 3,8 sd 4,2 dengan tingkat variansi sebesar 0,01.

\subsection{Analisis Kuantitatif Statistik Diskriptif.}

Tingkat kepercayaan mahasiswa terhadap teknologi yang digunakan dalam Blended Learning diukur dari nilai mean Perceived ease of used-PEU dan Perceived Usefulness-PU. Analisis terhadap nilai mean dari Tabel 3. Variabel Persepsi Kemudahan Penggunaan (Perceived ease of used-PEU) memperoleh nilai mean sebesar 4,2 (84\%) dengan seluruh dimensi mencapai nilai $>4,0(>80 \%)$. Hal ini berarti bahwa Kemudahan Penggunaan media pembelajaran yang dalam Blended Learning dilihat dari dimensi kemudahan dipelajari, interaksi, fleksibilitas, dan penggunaan pada kategori Sangat Baik. Untuk mempelajari media E-Learning (Google Classroom) tidak memerlukan syarat pendidikan khusus, Fleksibilitas alat, waktu dan tempat merupakan dimensi yang memiliki nilai paling tinggi pada variabel ini yaitu 4,4 (89\%).

Variabel Persepsi Kemanfaatan (Perceived Usefulness-PU) memperoleh nilai mean sebesar 3,9 (79\%) kategori Baik. Kemanfaatan dilihat dari dimensi efisiensi, peningkatan kinerja pembelajaran, dan efektifitas pencapaian hasil belajar. Dengan seluruh dimensi kemudahan penggunaan mencapai nilai $>3,7(>70 \%)$, khusus untuk dimensi meningkatkan kinerja mencapai nilai 4,0 (80\%). Hal ini berarti bahwa Kemanfaatan model pembelajaran Blended Learning dari dimensi efisiensi dan efektifitas dirasa Baik dengan manfaat peningkatan kinerja Sangat Baik.

Tingkat penerimaan mahasiswa terhadap teknologi yang digunakan dalam Blended Learning diukur dari nilai mean Attitude toward use - ATU, Behavioral Intention-BI, Actual Usage-AU. Variabel Sikap penggunaan (Attitude toward use - ATU) memperoleh nilai mean sebesar 3,8 (76\%). Hal ini berarti bahwa model pembelajaran Blended Learning disikapi secara positif oleh para mahasiswa dengan kategori nilai Baik. Dengan dimensi Kesenangan, kenyamanan, dan kepuasan pada kategori baik dengan nilai > 3,70 (>70\%), sedangkan dimensi penerimaan Sangat baik dengan nilai 4,0 ( 80\%)

Variabel Niat berperilaku (Behavioral Intention-BI) memperoleh nilai mean sebesar 4,0 (80\%). Hal ini berarti bahwa motivasi para mahasiswa terhadap penggunakan model Blended Learning pada kategori Sangat Baik. Mahasiswa mempunyai motivasi untuk terus menggunakan Blended Learning dan memotivasi pengguna lain pada kategori Sangat Baik mencapai nilai $\geq 4,0(\geq 80 \%)$. Dimensi mengembangkan diri mencapai nilai 3,9 (78\%) terkategorikan baik. 
Variabel Perilaku Nyata (Actual Usage-AU) memperoleh nilai mean sebesar 3,8 (76\%). Hal ini berarti bahwa perilaku nyata dari para mahasiswa dalam model pembelajaran Blended Learning sudah pada kategori Baik. Dengan dimensi frekuensi penggunaan pada kategori baik dengan nilai $>3,70(>70 \%)$. Frekuensi penggunaan diukur dari ferkuensi akses E-Learning (online) serta kehadiran pada tatap muka di kelas (offline) dan durasi penggunaan (dalam jam kuliah maupun diluar jam kuliah). Dimensi peruntukkan Sangat baik dengan nilai 4,1 (81\%). Penggunaan teknologi terutama diperuntukan untuk akses informasi, pengelolaan tugas-tugas perkuliahan dan interaksi dengan dosen maupun dengan mahasiswa lainnya. Artinya perilaku mahasiswa sudah sesuai dengan tujuan penggunaan teknologi untuk dimanfaatkan sebagai alat bantu pembelajaran.

Secara umum penggunaan model pembelajaran Blended Learning memperoleh nilai rata-rata (mean ) dari seluruh variabel mencapai nilai 3,94 (79\%). Hal ini berarti tingkat kepercayaan dan penerimaan Blended learning pada kategori Baik (mendekati sangat baik).

\subsection{Analisa Kualitatif Pandangan Umum Mahasiswa.}

Jawaban mahasiswa terhadap pertanyaan terbuka yang menanyakan persepsi umum mereka menunjukkan hal-hal positif dan hal-hal yang masih perlu diperbaiki/ditingkatkan. Hal-hal positif yang diperoleh dari model pembelajaran Blended Learning adalah :

1. Blended Learning dapat mengefisienkan waktu pembelajaran, terutama mahasiswamahasiswa yang mempunyai kesibukan lain selain kuliah.

2. Dengan Blended Learning pembelajaran jadi lebih fleksibel dalam waktu dan tempat.

3. Blended Learning mempermudah interaksi antara dosen dengan mahasiswa.

4. Blended learning mempermudah mendapatkan informasi dari dosen langsung, mempermudah pengumpulan tugas.

5. Blended learning sangat bermanfaat guna meningkatkan keahlian dalam sistem pembelajaran masa depan.

Hal-hal yang menjadi kekurangan dan perlu ditingkatkan adalah :

1. Belum semua dosen menggunakan Blended Learning.

2. Beberapa dosen belum mengoptimalkan fitur E-Learning.

3. Masih terkendala dengan sarana akses, perangkat (ponsel), jaringan.

4. Perlu ada panduan dalam bentuk Tutorial yang lengkap dalam pemanfaatan E-Learning.

5. Perlu dorongan kemandirian mahasiswa dalam belajar, beberapa mahasiswa belum memanfaatkan E-Learning secara optimal.

6. Respon dosen terhadap pertanyaan dan tanggapan mahasiswa yang disampaikan secara online dalam media E-Learning masih perlu ditingkatkan.

Secara umum mahasiswa mengapresiasi positif penggunaan model pembelajarn Blended Learning, walaupun ada catatan-catatan perbaikan. Media E-Learning diterima dengan baik sebagai sarana interaksi dalam pembelajaran, tetapi perkuliahan secara offline (tatap muka kelas) tetap diperlukan. Tatap muka di kelas diperlukan untuk menguatkan pemahaman mahasiswa dalam penguasaan materi pembelajaran.

\section{KESIMPULAN DAN SARAN}

\subsection{Kesimpulan}

Penerimaan model pembelajaran Blended Learning dikalangan mahasiswa secara umum dapat diterima dengan "Baik" mendekati "Sangat Baik". Nilai rata-rata (mean ) dari seluruh variabel mencapai nilai 3,94 (79\%). Dari aspek kemudahan penggunaan, teknologi yang dipakai Sangat Baik, artinya sangat mudah digunakan. Aspek Kemanfaatan dipersepsikan Baik, artinya bermanfaat dalam proses pembelajaran. Mahasiswa menunjukan 
sikap yang positif, direpresentasikan dengan nilai Baik. Mahasiswa sangat termotivasi dalam pembelajaran hal ini ditunjukkan dengan nilai niat berperilaku pada kategori Sangat baik. Perilaku mahasiswa dalam proses pembelajaran dalam kategori Baik, artinya sudah sesuai dengan tujuan penggunaan teknologi untuk meningkatkan aktifitas pembelajaran di kalangan mahasiswa sebagai subyek belajar.

\subsection{Saran}

Perlu dilakukan standarisasi pengunaan Blended Learning khususnya penggunaan media pembelajaran online (E-Learning) yang dikelola oleh administrator institusi, terintegrasi dengan sistem informasi akademik. Motivasi mahasiswa sudah baik maka perlu diimbangi dengan aktifitas dosen, terutama matakuliah yang belum menggunakan model pembelajaran Blended Learning.

\section{DAFTAR PUSTAKA}

Alharbi, S., \& Drew, S. (2014). Using The Technology Acceptance Model In Understanding Academics' Behavioural Intention To Use Learning Management Systems. International Journal of Advanced Computer Science and Applications, 5(1), 143-155.

Davis, F. D. (1989). Perceived usefulness, perceived ease of use, and user acceptance of information technology. MIS Quarterly, 13(3), 319-340. https://doi.org/10.2307/249008

Fatmawati, E. (2015). Technology Acceptance Model (TAM) Untuk Menganalisis Penerimaan Terhadap Sistem Informasi di Perpustakaan. IQRA': Jurnal Perpustakaan Dan Informasi, 9(1), 1-13.

Husamah. (2014). Pembelajaran Bauran (Blended Learning). Jakarta: Prestasi Pustaka.

Librado, D. (2017). Analisis Penerimaan Mahasiswa Terhadap Sistem Informasi Akademik (SIAKAD) Dengan Metode Technology Acceptance Model (TAM). Jurnal SAINTEKOM, 7(2), 112-125.

Mutawa, A. M. (2017). Evaluation of Blended Learning in Higher Education : A Case Study. PEOPLE : International Journal of Social Sciences, 3(1), 881-889.

Poluan, F., Lumenta, A., \& Sinsuw, A. (2014). Evaluasi Implementasi Sistem E-Learning Menggunakan Model Evaluasi Hot Fit: Studi Kasus Universitas Sam Ratulangi. EJournal Teknik Informatika, Ratulangi, Universitas S A M Studi, Program Informatika, Teknik Teknik, Fakultas Ratulangi, Universitas Sam Kampus, Jl Bahu, Unsrat, 4(2), 16.

Purnomo, A., Ratnawati, N., \& Aristin, N. F. (2016). Pengembangan Pembelajaran Blended Learning Pada Generasi Z. JTP2PS, 1, 70-77.

Saptomo, W. L. Y. (2018). Ragam Media Interaktif Dalam Pembelajaran. Semarang: BPUNISBANK.

Sugiyono. (2012). Metode Penelitian Kuantitatif Kualitatif dan R\&D. Bandung: Alfabeta.

Wijaya, M. (2012). Pengembangan Model Pembelajaran e-Learning Berbasis Web dengan Prinsip e-Pedagogy dalam Meningkatkan Hasil Belajar. Jurnal Pendidikan Penabur, 11(4), 20-37. 